\title{
DYLAN THOMAS
}

\section{"No entres con calma en esa noche errante"}

No entres con calma en esa noche errante.

La vejez debe arder en el ocaso:

lucha contra la luz agonizante.

Si los sabios aceptan lo humillante, sus palabras no doman el chispazo.

No entres con calma en esa noche errante.

Los buenos, tras la ola deslumbrante, evocan su pasado ante el mar raso:

lucha contra la luz agonizante.

Los audaces aceptan el diamante del sol, aunque su canto sea un fracaso: no entres con calma en esa noche errante.

Los más serenos, en la luz distante, ven, sin embargo, de la sombra el trazo: lucha contra la luz agonizante.

Padre mío, a la altura del fracaso, dame tu bendición, maldice acaso. No entres con calma en esa noche errante: lucha contra la luz agonizante. 